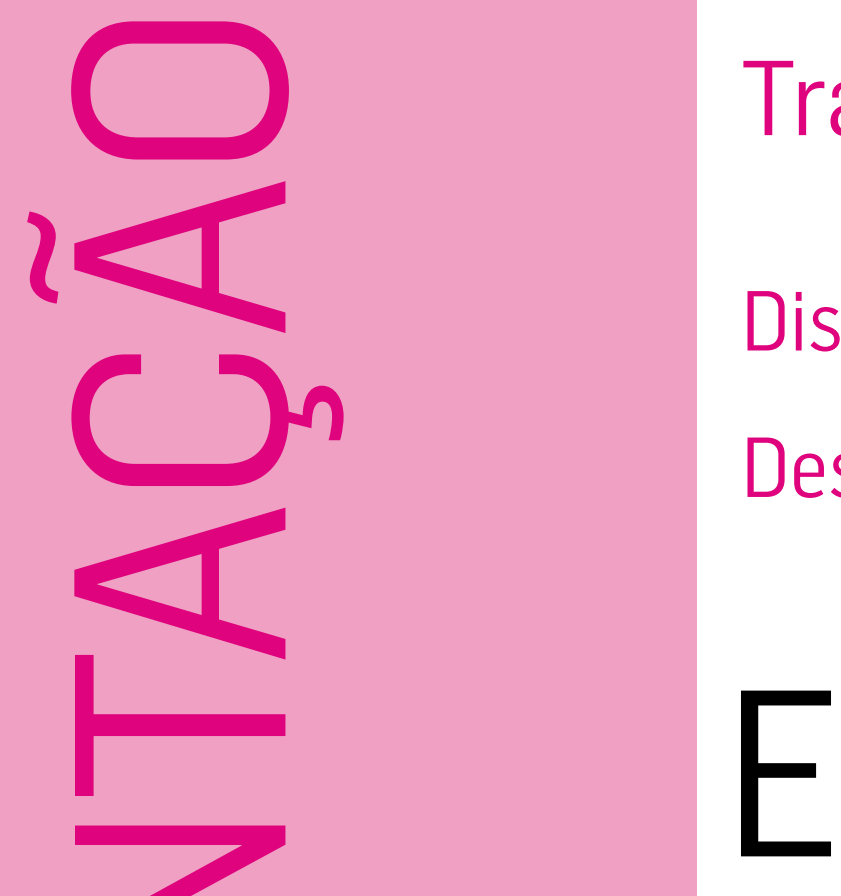

\title{
Transbordo de desinformação
}

\section{Disinformation overflow}

\section{Desbordamiento de desinformación}

em um simulacro da realidade produzido por plataformas e seus algoritmos, que o amplificam ou restringem conforme os interesses e orientações políticas de cada usuário. 0 resultado tem se mostrado desastroso: desinformação, retrocessos e controle.
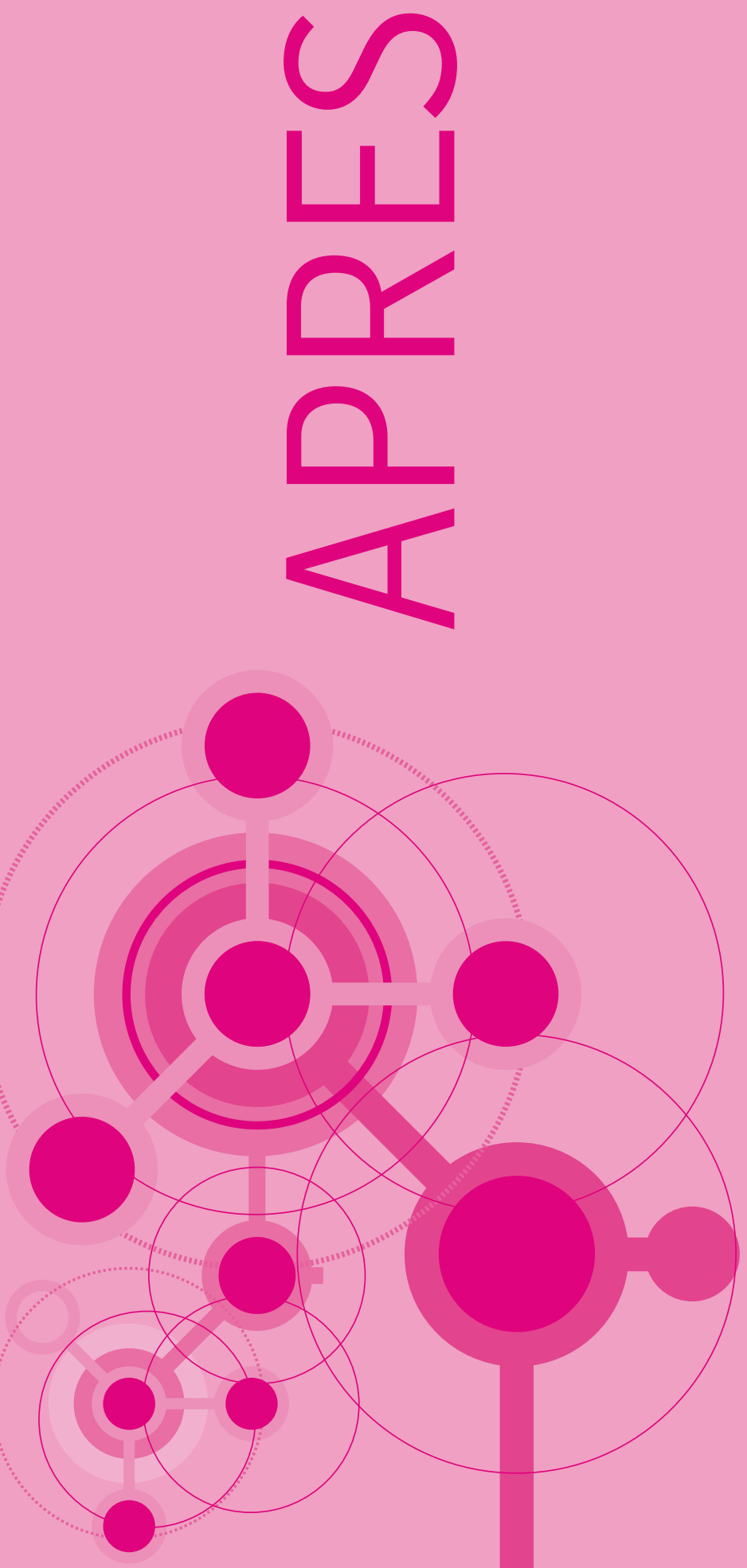

Para expor e problematizar esse cenário, a Organicom congrega artigos dedicados à discussão do impacto das fake news e das plataformas digitais na difusão de inverdades e na fragilização da democracia. 0 artigo de Pollyana Ferrari e Margareth Boarini abre o dossiê "Desinformação e comunicação na sociedade contemporânea" com uma reflexão acerca dos fenômenos da desinformação, das fake news e do negacionismo, apontando para o estímulo ao pensamento crítico das audiências como ação efetiva para o combate desse "parasita do século XXI". Em seguida, Rejane de Oliveira Pozobon e Bruno Kegler repercutem a influência dos fenômenos das fake news e da pós-verdade sobre a formação da opinião pública na sociedade de plataformas. Na sequência, em "Comunicação e dispositivo no espaço corporativo: uma reflexão sobre a estratégia da promessa na dinâmica das organizações no capitalismo", Eugênio Rondini Trivinho e Daniela Norcia discutem o conceito de dispositivo de comunicação a partir da biopolítica de Michel Foucault para pensar a comunicação como estratégia da reprodução do capitalismo. Luiz Alberto de Farias, Ivelise Cardoso e Paulo Nassar discutem a construção da pós-verdade a partir da disseminação de notícias falsas por algoritmos e a influência de redes sociais digitais na tomada de decisão e formação de opinião. 0 artigo "Vigilância, controle e atenção: a desinformação como estratégia", escrito pela professora Ana Regina Rego, complementa os debates, encerrando o dossiê.

A entrevista deste número foi concedida por Sergio Amadeu da Silveira, professor da Universidade Federal do ABC (UFABC), pesquisador de redes digitais e um dos coordenadores do Laboratório de Tecnologias Livres da UFABC. Amadeu, doutor em Ciência Política pela Faculdade 
de Filosofia, Letras e Ciências Humanas da Universidade de São Paulo, avalia criticamente o atual cenário de desinformação que estamos vivenciando a partir de fatores históricos e políticos. Ao longo da entrevista, o pesquisador discute a atuação da mídia e das redes sociais digitais na produção e propagação de desinformação, o controle de dados por plataformas digitais e seus impactos sobre o acesso a dados, informação e formação de opinião.

O Espaço Aberto, dedicado a artigos sobre temas diversos, traz, nesta edição, o relato de Fábia Pereira Lima e Rafaela Pereira Lima sobre o Laboratório Agência de Comunicação Solidária, fruto da parceria do curso de Relações Públicas da Universidade Federal de Minas Gerais com uma organização da sociedade civil, que tem promovido o protagonismo dos estudantes e lhes possibilitado a vivência dos impactos sociais de sua futura profissão. Nessa seção há, ainda, o artigo de Andre Rehbein Sathler Guimarães e Roberto Campos da Rocha Miranda, que traça o perfil do imaginário das maiores empresas brasileiras a partir da análise de suas declarações de visão.

A edição é finalizada com duas resenhas: Giovandro Marcus Ferreira analisa o livro de Claudiane Carvalho, A construção da notícia: interseções entre jornalismo e comunicação estratégica e Ivelise de Almeida Cardoso apresenta Os engenheiros do caos, obra do cientista político italiano Giuliano Da Empoli.

Com essa iniciativa, a Organicom-Revista Brasileira de Comunicação Organizacional e Relações Públicas espera ter contribuído, enquanto publicação científica, para o debate de questões extremamente atuais, intimamente relacionadas à Comunicação e imprescindíveis ao fortalecimento da Democracia.

Boa leitura! 